Г.А. ТІХОСОВА, Г.А. БОЙКО, А.В. КАПІТОНОВ

Херсонський національний технічний університет

\title{
СПОЖИВНІ ХАРАКТЕРИСТИКИ КОНОПЛЯНИХ ВОЛОКОН РІЗНИХ СРОКІВ ЗБИРАННЯ СТЕБЕЛ СОЛОМИ
}

\author{
А.А. ТИХОСОВА, Г.А. БОЙКО, А.В. КАПИТОНОВ \\ Херсонский наииональный технический университет \\ ПОТРЕБИТЕЛЬСКИЕ ХАРАКТЕРИСТИКИ КОНОПЛЯНЫХ \\ ВОЛОКОН РАЗНЫХ СРОКОВ УБОРКИ СТЕБЛЕЙ СОЛОМЫ
}

\section{A. TIKHOSOVA, G. BOYKO, A. KAPITONOV Kherson national technical University \\ CONSUMER PROPERTIES OF HEMP FIBER DIFFERENT STALK COLLECTION PERIODS}

\section{https://doi.org/10.36910/6775-2310-5283-2020-13-20}

Мета. Визначення споживних характеристик конопляних волокон, одержаних із лубу після збирання стебел соломи на зеленець і на насіння після повної зрілості.

Методика. В дослідженнях використані стандартні методи, викладені в існуючих нормативних документах. Довжина волокон $i$ ïх відсотковий розподіл, текс, лінійна щзільність визначались за ДСТУ ISO 6989:2005 «Волокна текстильні» та ДСТУ ISO 5084:2004 «Визначення товщини текстильних матеріалів та виробів».

Результати. Встановлено, що волокно виділене після поглибленої переробки лубу, отриманого зі стебел соломи після повної стиглості на насіння має високу лінійну щільність - 3,2-5,6 текс, яке придатне тільки для виготовлення грубих кручених виробів, тарних тканин та мішковини. Ціна таких волокон на світовому ринку дорівнює 8600 грн/m. Волокно, отримане після поглибленої переробки лубу, виділеного із стебел соломи зеленцевого збирання відрізняється достатньою тониною - 0,7-0,8 текс, що відповідає лінійній щільності котоніну. Таке волокно може бути використане для виготовлення виробів різноманітного призначення: тканин, для пошиття білизни, одягу, взуття, целюлози, паперу. Конопляне котонізоване волокно є цүінною цчеллюлозовмісною сировиною, коштує таке волокно на світовому ринку 28500 грн/m.

Наукова новизна. Вперше визначені споживні характеристики конопляних волокон виділених із лубу, щзо одержуються зі стебел соломи конопель різних строків збирання на зеленець та на насіння після повної стиглості стебел.

Практична значимість. Проведені експериментальні дослідження дадуть можливість визначати строки збирання стебел конопель для одержання волокон того чи іншого призначення в залежності від наявності попиту виробників на готові конопляні вироби та товари різноманітного призначення.

Ключові слова. технічні коноплі, строки збирання, волокно, лінійна щільність луб, зеленецьь. 


\section{Постановка проблеми у загальному вигляді та її зв'язок із} важливими науковими чи практичними завданнями. Украйнський ринок конопляного волокна й виробів із нього не має такої ємкості, як європейський, проте саме на цьому сучасному та інноваційному сегменті Україна зможе зайняти тверді позиції. На сьогоднішній день близько 100 компаній розглядають цей напрямок для розширення свого агробізнесу [1]. Але, у більшості випадків українські підприємці займаються насіннєвим матеріалом технічних конопель, а стеблова маса практично не використовується. Перепоною для переробки стеблової маси для вітчизняних аграріїв $\epsilon$ відсутність сучасних переробних підприємств, застаріла нормативна документація щодо переробки даної культури та відсутність наукової літератури, яка в повній мірі визначала придатність зібраної сировини до переробки.

3 цією метою були проведені глибокі дослідження, які спрямовані на детальний науковий аналіз всіх етапів технологічного процесу переробки конопляної сировини.

Як відомо, технологічний процес переробки стебел соломи конопель складається зі збирання, приготування трести та іï подальшої механічної обробки. Перша стадія технологічного процесу одержання конопляного волокна - це збирання та підготовки технічних конопель до переробки. Ці операції $є$ головними та вирішальними етапами процесу вирощування конопель, а також характеризуються високою трудомісткістю.

В Україні на даний час застосовуються дві технології збирання технічних конопель:

- технологія збирання конопель на двостороннє використання сировини на насіння та волокно;

- технологія зеленцевого збирання конопель тільки на волокно.

Але до цього часу не встановлено наскільки змінюються споживні властивості конопляних волокон після переробки стебел соломи після різних строків збирання, тому залишається невирішеним питання для яких цілей у майбутньому може бути використане волокно після зеленцевого збирання i після збирання стебел на насіння.

Аналіз останніх досліджень, у яких започатковано вирішення проблеми. В останніх дослідженнях, які проведені вченими Інституту луб'яних культур Гілязетдіновим Р.Н., Коропченко С.П. [2] та Херсонського національного технічного університету Тіхосовою Г.А., Бойко Г.А. [3] доказано, що строки збирання стебел соломи технічних конопель відіграють 
найважливішу роль у формуванні фізико-механічних характеристик конопляного волокна після механічної переробки стебел. Але в даних роботах відсутня повна інформація 3 впливу різних строків збирання на споживні характеристики волокна. Тому актуальним завданням коноплеперобної галузі на даний час $є$ визначення товарознавчих властивостей конопляної сировини 3 метою її подальшої переробки в конкурентоспроможні товари.

Цілі статті. Дослідження споживних характеристик конопляних волокон одержаних із лубу стебел технічних конопель зеленцевого збирання та збирання стебел після повної стиглості на насіння.

Об'єкт дослідження. Для здійснення наукових досліджень обрано нові сорт технічних конопель, виведених Інститутом луб'яних культур НААНУ та зібраних в різні строки стиглості (зеленцева, повна стиглість), який районовано та поширено в Україні - Гляна.

Методи дослідження. Зразки лубу конопель сорту Гляна, одержаного в результаті механічної обробки стебел соломи після зеленцевого збирання та стебел, зібраних після повної стиглості, були передані на підприємство ТОВ «АгроХанф» для поглибленої переробки їх на волокно.

Волокно було перероблене традиційним способом, 3 використанням м'яльно-тіпальних агрегатів. У результаті поглибленої переробки двох видів лубу було отримано волокно та здійснено оцінювання його споживних характеристик з метою встановлення сортності зразків волокна й розробки рекомендацій із вибору сфери їх подальшого застосування. Довжину волокон і їх розподіл за довжиною визначали шляхом вимірювання довжини окремих волокон за ДСТУ ISO 6989:2005 «Волокна текстильні. Методи визначення довжини волокон і розподілу за довжиною штапелю вимірювання окремих волокон». Лінійну щільність волокон розраховували згідно 3 ТУ 17 У 00306710.079-2000 «Котонин из короткого льняного волокна. Технические условия» та ДСТУ ISO 5084:2004 «Визначення товщини текстильних матеріалів та виробів». Вміст костриці та міцність волокна визначали за ГОСТ 23406-78 «Пенька трепаная, поставляемая для экспорта. Технические условия».

Виклад основного матеріалу дослідження 3 повним обгрунтуванням отриманих наукових результатів. Ефективна первинна обробка стебел технічних конопель неможлива без якісної підготовки їх до цього процесу. Тому збирання є одним із головних етапів у процесі підготовки сировини до переробки та має суттєвий вплив на якість вихідної продукції. 
Спираючись на вищевикладене для проведених досліджень було обрано конопляну сировину після двох технологій збирання: зеленцевої та повної стиглості. Технологія збирання конопель під час повної стиглості потребує застосування спеціального комплексу коноплезбиральних машин. Найбільш поширеною є роздільна технологія із застосуванням коноплежатки ЖК-1,9 для скошування стебел і формування їх у снопи та коноплемолотарки МЛК 4,5, яка призначена для обмолоту снопів [4].

Інший відомий спосіб збирання технічних конопель, який застосовується як в Україні, так і у більшості розвинутих країн світу - це прогресивна технологія зеленцевого збирання конопель [5]. Дана технологія призначена тільки для одержання волокна. Вона базується на переході від механізації окремих виробничих операцій до механізації технологічного процесу в цілому та практично виключає ручну працю завдяки використанню рулонного преса для збирання трести. На основі класифікації конопляних волокон різного функціонального призначення за головними показниками якості, наведеної в монографії науковців ХНТУ Чурсіної Л.А., Богданової О.Ф., Ляліної Н.П., Резвих Н.I. [6], визначено сферу подальшого застосування волокон, отриманих із лубу після різних строків збирання стебел соломи конопель.

Результати дослідження споживних характеристик конопляних волокон, отриманих із лубу зеленцевого збирання та збирання після повної стиглості стебел, подано в таблиці 1.

Таблиця 1

Споживні характеристики конопляних волокон, отриманих із лубу після зеленцевого збирання та збирання стебел після повної стиглості

\begin{tabular}{|c|c|c|c|c|}
\hline \multirow[t]{2}{*}{ Показник якості } & \multirow{2}{*}{\multicolumn{2}{|c|}{$\begin{array}{c}\text { За нормативними } \\
\text { документами на } \\
\text { котонін }\end{array}$}} & \multicolumn{2}{|c|}{$\begin{array}{l}\text { Волокна після різних строків збирання } \\
\text { стебел }\end{array}$} \\
\hline & & & повна стиглість & зеленцеве \\
\hline Вміст костриці ,\% & \multicolumn{2}{|c|}{$1,0-4,0$} & 5 & 3 \\
\hline $\begin{array}{l}\text { Лінійна щільність, } \\
\text { текс }\end{array}$ & \multicolumn{2}{|c|}{$0,1-1,0$} & $3,2-5,6$ & $0,7-0,8$ \\
\hline $\begin{array}{l}\text { Міцність, даН } \\
\text { Розподіл волокон за }\end{array}$ & \multicolumn{2}{|c|}{$18,0-25,0$} & $18,2-25,0$ & $20,3-26,5$ \\
\hline $\begin{array}{l}\text { групами довжин, } \\
\text { мм: }\end{array}$ & \multirow{2}{*}{\multicolumn{2}{|c|}{$\begin{array}{l}\text { не більше } \\
15\end{array}$}} & 2 & 3 \\
\hline $5-15$ & & & 3 & 2 \\
\hline \multirow{5}{*}{$\begin{array}{r}15-20 \\
20-30 \\
30-40 \\
40-45 \\
\text { понад } 45\end{array}$} & \multirow{5}{*}{\multicolumn{2}{|c|}{$\begin{array}{l}\text { не менше } \\
75\end{array}$}} & 5 & 5 \\
\hline & & & 10 & 10 \\
\hline & & & 10 & 10 \\
\hline & & & 15 & 60 \\
\hline & & & 55 & 10 \\
\hline
\end{tabular}


За результатами досліджень аналіз даних таблиці 1 свідчить, що волокон, виділене після поглибленої переробки лубу, отриманого зі стебел соломи повної стиглості, має високу лінійну щільність - 3,2-5,6 текс. Вміст волокон 3 довжиною понад 45 мм досягає $55 \%$, тобто одержане волокно є грубим i достатньо довгим. Таке волокно може бути використане для виготовлення грубих тарних тканин, мішковини, кручених виробів. Згідно з ГОСТ 23406-78 це волокно оцінено третім сортом. Воно йде на експорт за ціною 8600 грн/т. Волокно, отримане після поглибленої переробки лубу, виділеного із стебел соломи зеленцевого збирання, відрізняється достатньою тониною - 0,70-0,80 текс, що відповідає лінійній щільності лляного котоніну. Це волокно має достатньо високих вміст волокон прядильної групи, близьких за своїми властивостями до бавовняного волокна. Так, відсоток волокон з довжиною 4045 мм становить $60 \%$ таке волокно може бути використане для виготовлення конопляної пряжі високої міцності, оскільки його розривне навантаження дорівнює 20,3-26,5 даН завдяки низькому вмісту костриці - 3-5 \% 3 цього волокна можна отримувати целюлозу, що підтверджено результатами досліджень Богданової О.Ф. [7]. Крім того, таке волокно може бути використане для одержання медичної вати після лужно-перекисного варіння. Таким чином, волокно, виділене з лубу після зеленцевого збирання, було оцінено за ГОСТ 23406-78 першим сортом. Воно може відправлятися на експорт за ціною 28500 грн/т. Дослідження якості волокон, одержаних із лубу конопель після зеленцевого збирання та збирання після повної стиглості стебел, використані для порівняльного аналізу економічної ефективності декортикації стебел соломи конопель різних строків збирання [8].

Висновки та перспективи подальших досліджень. Аналіз проведених розрахунків споживних властивостей волокон технічних конопель після різних строків збирання визначив товарну здатність використання даних волокон в різних галузях промисловості. Дані розрахунки допоможуть переробникам конопляної сировини, знаючи технологічний процес збирання, заздалегідь планувати подальше використання волокон та їх сфери збуту.

\section{Список використаних джерел}

1. $\quad$ European Industrial Hemp Association (EIHA) [Электронный ресурс]. - Режим доступу: http://eiha.org/?login=failed\&errcode=empty_username.

2. Коропченко С.П., Гілязетдінов Р.Н., Лукяненко П.В., Баранник В.Г., Мешков Ю.Є. Шляхи удосконалення технології збирання та переробки насіння конопель. Легка промисловість. 2006. № 2. С. 46-47. 
3. Бойко Г.А., Тіхосова Г.А., Кутасов А.В.. Вплив способів збирання на технології переробки та сфери подальшого використання конопляної сировини. Вісник Херсонського національного технічного університету. 2018. № 1 (64). С. 75-80.

4. Гілязетдінов Р.Н., Клевцов К.М. Збирання та первинна переробка конопель на сучасному етапі розвитку галузі. Проблемы легкой и текстильной промышленности Украины. 2008. № 1 (14). С.83-84.

5. Котонин из короткого льняного волокна. Технические условия: ТУ $17 \mathrm{У}$ 00306710.079 - 2000. [Введены 2000-01-08]. - Херсон: Государственный комітет Украины по стандартизации, метрологи и сертификации «Херсонский ГЦСМС» (Хнрсонский ХБК), 2000. - 17 с. (Хехнические услович Украины).

6. Товарознавство і стандартизація продукції безнаркотичних конопель: [монографія] / [Чурсіна Л.А., Богданова О.Ф., Ляліна Н.П., Резвих Н.І.]; під ред. Л.А. Чурсіної. Херсон: ПП Вишемирський В.С., 2012. 308 с.

7. Богданова О.Ф., Ляліна Н.П., Резвих Н.I. Обгрунтування необхідності розроблення національних стандартів на целюлозні вироби з безнаркотичних конопель. Стандартизаиія, сертифікаиія, якість. 2012. №6(79). С. 23-29.

8. Бойко Г.А., Тіхосова Г.А., Кутасов А.В. Економічна ефективність одержання целюлозовмісних товарів 3 технічних конопель за різних строків збирання стебел. Товарознавчий вісник. 2019. №12. С. 66-74.

\section{References}

1. European Industrial Hemp Association (EIHA) [Elektronnyiy resurs]. - Rezhim dostupu: http://eiha.org/?login=failed\&errcode=empty_username

2. Koropchenko S.P., GIlyazetdInov R.N., Lukyanenko P.V., Barannik V.G., Meshkov Yu.E. (2006). Shlyahi udoskonalennya tehnologIYi zbirannya ta pererobki nasInnya konopel. Legka promislovist. 2. 46-47.

3. Boyko G., Tihosova A., Kutasov A. (2018). Vpliv sposobIv zbirannya na tehnologiy pererobki ta sferi podalshogo vikoristannya konoplyanoiy sirovini. Visnik Hersonskogo natsIonalnogo tehnIchnogo universitetu. 1 (64). 75-80.

4. Gilyazetdinov R.N. (2008). Zbirannya ta pervinna pererobka konopel na suchasnomu etapI rozvitku galuzi. Problemyi legkoy i tekstilnoy promyishlennosti Ukrainyi. 1 (14). 83-84.

5. Kotonin iz korotkogo lnyanogo volokna. Tehnicheskie usloviya: TU $17 \mathrm{U}$ 00306710.079 - 2000. - [Vvedenyi 2000-01-08]. - Herson: Gosudarstvennyiy komItet Ukrainyi po standartizatsii, metrologi i sertifikatsii «Hersonskiy GTsSMS» (Hnrsonskiy HBK), 2000. - 17 s. (Hehnicheskie uslovich Ukrainyi).

6. Tovaroznavstvo i standartizatsIya produktsiy beznarkotichnih konopel: [monografIya] / [ChursIna L.A., Bogdanova O.F., LyalIna N.P., Rezvih N.I.]; pId red. L.A. ChursInoYi. Herson: PP Vishemirskiy V.S., 2012. 308.

7. Bogdanova O.F. (2012). Obgruntuvannya neobhidnosti rozroblennya natsionalnih standartiv na tselyulozni virobi z beznarkotichnih konopel. StandartizatsIya, sertifIkatsIya, yakist 6(79). 23-29.

8. Boyko G.A. (2019). Ekonomichna efektivnist oderzhannya tselyulozovmisnih tovariv z tehnichnih konopel za riznih strokiv zbirannya stebel. Tovaroznavchiy visnik. 12. 66-74.

Цель. Определение потребительских характеристик конопляных волокон, полученных из луба после уборки стеблей соломы на зеленеи и на семена после полной зрелости.

Методика. В исследованиях использованы стандартные методы, изложенные в существуюших нормативных документах. Длина волокон и их процентное распределение, 
текс, линейная плотность определялись по ДСТУ ISO 6989: 2005 «Волокна текстильные» и ДСТУ ISO 5084: 2004 «Определение толщины текстильных материалов».

Результаты. Установлено, что волокна выделенные после углубленной переработки луба, полученного из стеблей соломы после полной спелости на семена имеют высокую линейную плотность - 3,2-5,6 текс, которое пригодно только для изготовления грубых крученых изделий, тарных тканей и мешковины. Цена таких волокон на мировом рынке равна 8600 грн/m. Волокно, полученное после углубленной переработки луба, выделенного из стеблей соломь зеленцевого сбора отличается достаточной тониной 0,7-0,8 текс, что соответствует линейной плотности котонина.

Научная новизна. Впервые определень потребительские характеристики конопляного волокна выделенного из луба, которые получают из стеблей соломы конопли различных сроков уборки на зеленеи и на семена после полной спелости стеблей.

Практическая значимость. Проведенные экспериментальные исследования дадут возможность определять сроки уборки стеблей конопли для получения волокон того или иного назначения в зависимости от наличия спроса производителей на готовые конопляные изделия и товары различного назначения.

Ключевые слова. техническая конопля, сроки уборки, волокно, линейная плотность луб, зеленец.

Purpose. Determination of consumer characteristics of hemp fibers obtained from the bast after harvesting green straw stems and mature stems to obtain seeds.

Methodology. The studies used standard methods outlined in existing regulatory documents. The length of the fibers and their percentage distribution, tex, linear density were determined according to DSTU ISO 6989: 2005 "Textile fibers" and DSTU ISO 5084: 2004 "Determination of thickness of textile materials".

Findings. It was found that the fibers extracted after deep processing of the bast obtained from the stalks of straw after full ripeness for seeds have a high linear density of 3.2-5.6 tex, which is suitable only for the manufacture of coarse twisted products, container fabrics and burlap. The price of such fibers in the world market is $8600 \mathrm{UAH} / \mathrm{t}$. The fiber obtained after deep processing of the bast extracted from the stalks of green straw is sufficiently thin 0.7-0.8 tex, which corresponds to the linear density of cotonin. Such fiber can be used for the manufacture of products for various purposes: fabrics, sewing clothes, clothes, shoes, pulp, paper. Hemp kotonizirovanny fiber is a valuable cellulose-compatible raw material, the price of such fiber on the world market is $28500 \mathrm{UAH} / \mathrm{t}$.

Originality. For the first time, the consumer characteristics of hemp fiber extracted from the bast, which is obtained from hemp stems of different times of collecting green stems and seeds after full maturity of the stems, were determined.

The practical value. The conducted experimental studies will make it possible to determine the timing of harvesting hemp stems to obtain fibers for one purpose or another, depending on the availability of manufacturers' demand for finished hemp products and goods for various purposes.

Keywords: technical hemp, harvest time, fiber, linear density of bast, green stems.

Саття рекомендовано до публікації доктором технічних наук. професором Херсонського НТУ Чурсіною Л.А. Дата надходження в редакиію 15.12.2019 р. 